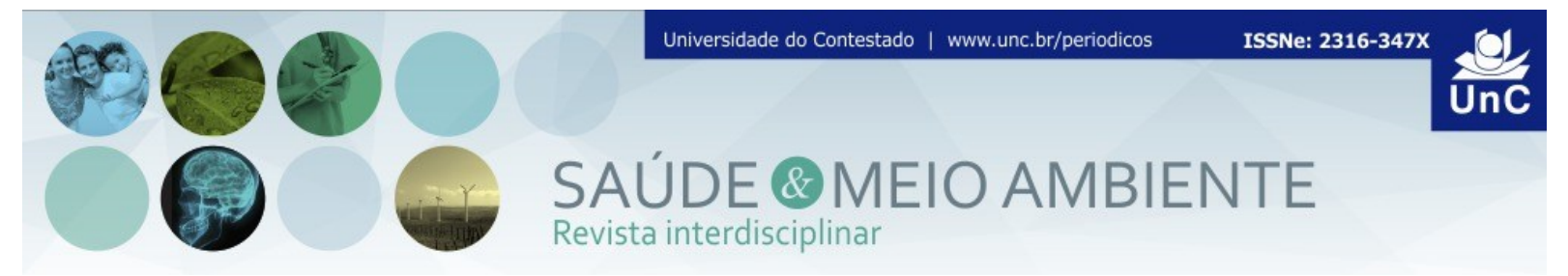

\title{
RESENHA DO LIVRO: AS MENINAS QUE NUNCA PERDERAM A GRAÇA, ADRIANA MORO
}

João Adolfo Maciel Monteiro ${ }^{1}$

De forma despretensiosa iniciei a leitura do livro "As meninas que nunca perderam a graça" de Adriana Moro. Fazendo parte de uma série que se denomina "para repensar o cuidado" estava eu preparado para uma leitura que me faria adentrar no mundo das ciências da saúde, em que poderia conhecer um pouco mais da realidade profissional de uma área tão delicada e que merece sim ser repensada constantemente. Apesar de ter minha formação nas humanidades, acho de extrema importância ter contato com outras ciências para ampliar os horizontes e conhecer outras realidades. Acredito que isso valha para qualquer ramo profissional.

Desde já reconheço que minha primeira impressão do livro estava completamente errada, e que o título e o nome da série nos faz enganar, bem como a pretensão da autora de ter um livro voltado para a área da saúde. Afirmo isso pois de sua proposta sobre repensar o cuidado deduzi que fosse refletir sobre como os profissionais de saúde podem estar mais próximos das pessoas, e daí eu poderia pensar em como eu estaria mais próximo tanto dos familiares espalhados pelo mundo, como dos que se encontram em minha casa, no meu cotidiano. Mais um engano. O nome da série "Repensar o Cuidado" oculta o que talvez realmente esteja por trás do livro, e seja a ilusão que mais surpreende quem lê, a busca por si mesmo no cotidiano, nas histórias que vivemos e por vezes não refletimos. E essa é uma busca que permeia todas as profissões.

E nessa busca por refletir as experiências vividas nos hospitais, nos plantões, Adriana leva o leitor para dentro de um mundo profissional e ao mesmo tempo mágico, pois é a luta pela vida que está presente em várias histórias, e como essa luta faz os personagens se reafirmarem com seres humanos, com grandes capacidades de amor. Isso é comovente. Depois que se inicia a leitura do livro parar de ler é muito difícil. E confesso que não parei, pois o meu interesse naquelas histórias verídicas, naqueles personagens só aumentava, justamente por saber serem eles reais transformavam tudo ainda mais surrealista e de uma proporção que poucas ficções podem entregar aos seus gigantes.

Pessoas comuns, nos seus cotidianos, são capazes de realizações dignas de Deuses Gregos, de heroísmos surpreendentes, de superar dificuldades, padrões e preconceitos que muitas vezes não percebemos, mas que ao superar nos constituem como seres humanos reais e melhores a cada dia, só é preciso um pouco de esforço e percepção para traspassar os desafios. Perceber essas histórias

\footnotetext{
${ }^{1}$ Graduado em Ciências Sociais pela Universidade Federal de Pernambuco. Graduado em Bacharelado em Direito na Universidade Católica de Pernambuco. Pós-graduado em Direito e Processo do Trabalho pela Faculdade Estácio do Recife. Mestrando em Direito Laboral pela Universidade de Coimbra. Pernambuco. Brasil. E-mail: joaoadolfo83@hotmail.com
} 
que poderiam passar como qualquer outra que vivenciamos no nosso cotidiano, principalmente nos nossos locais de trabalho, é o grande trunfo do personagem que permeia todas elas, a autora do livro.

Um observador atento aos detalhes, disposto a ajudar, e ansioso por entender o que se passa com o outro, em si colocar no lugar de quem não é, em ver nas menores ações, nos pequenos gestos um sinal de carinho, de boa vontade, de intuito de esforço para ser melhor. Isso não é pouco, e além de perceber conseguir refletir sobre cada detalhe é o que mais chama atenção. A autora/ personagem, observador atento, nos traz de forma muito cuidadosa histórias de buscas pelo autoconhecimento, pela felicidade, de conseguir olhar o cotidiano de forma mais acalentadora em momentos tão difíceis, onde a realidade parece ser realmente uma ficção e a necessidade de humanização nos ambientes hospitalares grita.

Não vejo o livro "As meninas que nunca perderam a graça" como uma forma de repensar o cuidado, vou um pouco mais além, vejo neste livro uma forma de encontrar sentido para seguir feliz na vida. $E$ isso é de extrema importância para os profissionais que lidam com a vida e a morte no seu cotidiano, como os da área de saúde, mas é importante para qualquer profissão, e para qualquer pessoa. Encontrar sentido para seguir feliz.

Vi isso na mãe prostituta que entregou sua filha para adoção, numa busca para que ela tivesse uma vida diferente da sua própria, bem como, no pai adotivo que mesmo sabendo dos riscos de morte daquela criança não titubeou em assumir a paternidade que lhe poderia ser tão fugaz, mais ser pai, poder cuidar, era o sentido da vida e da felicidade que ele buscava. Vi também na jovem que dentro das suas limitações conseguia se produzir e postar uma foto onde ela se reconhecia como linda e atraente, como realmente acredito que ela tenha sido. Vi a busca por sentido e felicidade na vida quando a mãe de um filho anencéfalo que havia se preparado para à morte subitamente se depara com a vida e não vacila, leva seu filho para casa e cuida dele até o fim do ciclo da vida, e sua fala para nossa personagem é nisso emblemática "agora acabou", não quando ela havia se preparado, mas quando havia de ser cumprido.

Vi tanto nas histórias do livro "As meninas que nunca perderam a graça" vi um observador que nos mostra o carinho, o cuidado, mas principalmente a vontade de ser feliz, de se auto-compreender em cada história. E isso é por um motivo simples, quando temos dentro de nós amor que não conseguimos conter, o qual nos traspassa e nos deixa com uns três metros de altura tamanha sua pulsão, não há olhar diferente, só podemos ver amor nas demais ações.

O livro "As meninas que nunca perdem a graça" de Adriana Moro é fantástico por ser real, assim como é fabuloso conhecer a pessoa sensível que escreveu o livro, que na sua visão de pesquisadora, observadora atenta, nos traz um livro que tenta repensar os cuidados que os profissionais de saúde podem ter no seu trabalho de forma didática, com perguntas ao final de cada capítulo mostrando o caminho de reflexão que ela própria deve ter percorrido ao escrevê-lo. 
O seu contributo para uma forma de cuidado mais atento é inegável, e a autora o faz de maneira suave e bela como esses momentos devem ser, apesar da intensidade com que se vive. Mas devo frisar que vi em cada história um amor, um carinho pela vida que tantas vezes parece difícil e a autora transforma em uma forma carinhosa de abordagem. E nisso, por todo o texto, vi uma pessoa com amor e coração que não cabem no seu corpo, e que entrega amor de forma tão intensa a despeito do tempo que esse possa durar. Agradeço pelo livro, me transformou e me fez ver ainda com mais amor as histórias do nosso dia-a-dia. 